\title{
Lactococcus lactis as a safe and inexpensive source of bioactive silver composites
}

\author{
Railean-Plugaru Viorica $^{1,2} \cdot$ Pomastowski Pawel $^{1,2} \cdot$ Meller Kinga $^{1,2} \cdot$ Zloch Michal $^{1,2}$. \\ Rafinska Katarzyna ${ }^{1,2} \cdot$ Buszewski Boguslaw ${ }^{1,2}$
}

Received: 7 February 2017 / Revised: 12 July 2017 / Accepted: 19 July 2017 /Published online: 25 August 2017

(C) The Author(s) 2017. This article is an open access publication

\begin{abstract}
This research develops a safe, inexpensive, and more accessible source for synthesis of silver nanoparticles. The bioactive silver composites synthesized by Lactococcus lactis 56 KY484989 (LCLB56-AgCs) were characterized by various physico-chemical techniques and investigated for their antimicrobial activity and cytotoxicity. The average amount of nanoparticles was $0.363 \pm 0.09 \mathrm{mg}$ from $50 \mathrm{~mL}$ of culture medium. The synthesis efficiency varied from 71 to $85 \%$. Synthesized silver nanoparticles with spherical in shape were found to be of 5-50 $\mathrm{nm}$ and average diameter $19 \pm 2 \mathrm{~nm}$. Based on the shape of isotopic pattern of d-electrons metals, the signals of silver isotopes $\left[{ }^{107} \mathrm{Ag}\right]^{+}$at $\mathrm{m} / \mathrm{z} 106.905$ and $\left[{ }^{109} \mathrm{Ag}\right]^{+}$at $\mathrm{m} / \mathrm{z}, 108.910$ were confirmed. Moreover, LCLB56-AgCs exerted an inhibitory effect against all tested bacterial strains (Pseudomonas aeruginosa ATCC10145, Proteus mirabilis ATCC25933, Staphylococcus epidermidis ATCC49461, MSSA ATCC29213, and Staphylococcus aureus ATCC6338). More pronounced antimicrobial effect was noticed for $15 \mu \mathrm{g} / \mathrm{well}$. Minimum inhibitory concentration required to inhibite the growth of $90 \%$ organism $\left(\mathrm{MIC}_{90}\right)$ of synthetized LCLB56$\mathrm{AgCs}$ was in a range of $3.125-12.5 \mu \mathrm{g} / \mathrm{mL}$. The concentration at which the viability of the L929 cells was reduced to $50 \%$ was above $200 \mu \mathrm{g} / \mathrm{mL}$ for LCLB56-AgNCs. These results open up possibilities for many applications of bioactive silver composites (BioAgCs) synthesized by L. lactis 56 in food and pharmaceutical industries.
\end{abstract}

Buszewski Boguslaw

bbusz@chem.umk.pl; bbusz@chem.uni.torun.pl

1 Department of Environmental Chemistry and Bioanalytics, Faculty of Chemistry, Nicolaus Copernicus University, Gagarina 7, 87-100 Torun, Poland

2 Interdisciplinary Centre of Modern Technology, Nicolaus Copernicus University, Wileńska 4, 87-100 Torun, Poland
Keywords Silver composites $\cdot$ Lactococcus lactis . Antibacterial activity $\cdot$ Cytotoxicity $\cdot$ Biosynthesis

\section{Introduction}

Nanotechnology involves the study of structures of size to ca. $100 \mathrm{~nm}$, which possess new properties and functions. Some of these new nanomaterials, especially those containing silver, exhibit a very efficient antibacterial effect. Currently, a lot of research refers to silver in the form of nanoparticles. They possess many advantages, i.e., exhibit antibacterial effect against a broad range of microorganisms (bacteria, fungus, parasites) and usually in antibacterial doses do not exert cytotoxic effect toward eukaryotic cells. These properties are very important in association with the emergence of pathogenic bacterial strains that possess a resistance even toward several antibiotics (Cherusova and Epple 2013; Singh et al. 2015a, b). Hence, the development of new antimicrobial solutions has become of increasing importance for medicine. Silver nanoparticles/composites in different forms constitute a very promising approach for the development of new antibacterial therapies against of the skin, throat, or ear infections.

There are physical and chemical methods available for synthesis of silver nanoparticles. Moreover, during the recent years, a wide range of metal composites, doped silver, and polymer/silver nanocomposites are a subject of increased interest (Humberto 2014, Ciobanu et al. 2015). However, most of them demand hazardous chemicals, toxic byproducts, and high energy consumption (Cherusova and Epple 2013). Recently, biological methods of silver nanoparticles synthesis using green algae, bacteria, fungi, and plant extracts are gaining impetus due to their low costs and simplicity (Singh et al. 2013; Salunke et al. 2014). The properties of synthesized 
nanoparticles depend on used bacterial strain, type of medium, $\mathrm{pH}$, and temperature. In this work, for the synthesis of bioactive silver composites, we chose Lactococcus lactis which belongs to both lactic acid bacteria (LAB) and probiotic groups.

Lactic acid bacteria are a clad of Gram-positive nonsporing cocci or rods with non-aerobic habit which produce lactic acid as the major metabolic end product of carbohydrate fermentation (Nejati et al. 2016). These microorganisms are found in milk and fermented products and in fermented vegetables and beverages. They inhibit the growth of pathogenic and deteriorating microorganisms. Most of them are residents of gastrointestinal microbiota which provides a microbial barrier against microbial pathogens. They can elicit innate and adaptive immune response by binding to specific receptors on immune cells (Quinto et al. 2014). Moreover, lactic acid bacteria produce bacteriocins that are small ribosomally synthesized proteins which possess antibacterial activity. They may act via pore forming, nuclease activity, or peptidoglycan production inhibition. Many studies proved that the application of bacteriocins is efficient barrier against pathogens.

The aim of this study was to develop inexpensive, simple, and fast method to synthesis of silver composites for future use in the food and pharmaceutical industries. Previous research indicated that biomass of lactic acid bacteria is a good reducing and capping agent for the efficient production of silver nanoparticles (Sintubin et al. 2009; Matei et al. 2015). In our study, we used supernatant of $L$. lactis liquid culture. The advantage of proposed method is the safe application of known to man LAB strain. Moreover, this strain is easy and not expensive to culture. The obtained LCLB56 composites were characterized by various physico-chemical techniques and investigated for their antimicrobial activity and cytotoxicity.

\section{Material and methods}

Effectiveness of LCLB56-AgCs was studied against following bacteria: Pseudomonas aeruginosa ATCC10145, Proteus mirabilis ATCC25933 (Collection of the Collegium Medicum of Nicolaus Copernicus University), S. epidermidis ATCC49461 from the collection of Centre for Modern Interdisciplinary Technologies, Nicolaus Copernicus University, Torun, MSSA ATCC29213 (methicillin-sensitive Staphylococcus aureus), and S. aureus ATCC6338 from Sanitary-Epidemiological Station in Torun. Mueller-Hinton $(\mathrm{MH})$ broth was purchased from Sigma-Aldrich (Germany), and a solution of phosphate buffered saline (PBS-10X) was supplied from GenoPlast (Poland). L929 mouse Cell Line from European Collection of Authenticated Cell Cultures. Dulbecco's modified Eagle medium (DMEM), glutamine, fetal bovine serum (FBS), and dimethyl sulfoxide (DMSO) were from Sigma-Aldrich. MTP Anchor Chip 384 target (Bruker Daltonik, Bremen, Germany) was used in matrix-assisted laser desorption ionization-time of flight (MALDI-TOF MS) experiments, as well as chemicals from Sigma-Aldrich. The milk was supplied by Dairy Factory in Drzycim, Poland. Water was purified using a Milli-Q RG system by Millipore (Millipore Intertech, Bedford, MA, USA).

\section{Isolation of bacteria from milk products}

The samples of milk were plated on M17 medium and incubated at $37^{\circ} \mathrm{C}$ for $24 \mathrm{~h}$. Then, the same combination of media was streaked with the obtained biological material using sterile inoculation loop and incubated at $37{ }^{\circ} \mathrm{C}$ for $24 \mathrm{~h}$. Subsequently, the grown colonies were applied for the preparation of dilutions in the range of $10^{-1}$ to $10^{-8}$ using sterilized $0.87 \% \mathrm{KCl}$ and double distilled water $\left(\mathrm{H}_{2} \mathrm{Odd}\right)$. All dilutions were plated ( $1 \mathrm{~mL}$ of inoculum) onto Petri dishes with culture media (M17) and then incubated at $37^{\circ} \mathrm{C}$ for $24 \mathrm{~h}$. Based on the visible morphological characteristics (i.e., color and texture of colony as well as shape, size and Gram staining of cells), one isolate was chosen for further analysis.

\section{Identification of the isolated bacterial strain by $16 \mathrm{~S}$ rDNA PCR}

For molecular identification, bacterial DNA was extracted from overnight cultures (TSB medium, $37^{\circ} \mathrm{C}$ ) using the kit for the isolation of genomic DNA from bacteria EXTRACTME (DNA Gdańsk, BLIRT S.A, Poland). DNA concentrations were determined using a UV-Vis spectrophotometer (NanoDrop 2000). Fragments of 16S ribosomal DNA (rDNA) were amplified using the primers 27F (5AGAGTTTGATCMTGGCTCAG-3) and 1492R (5GGTTACCTTGTTACGACTT-3). An amplification reaction was performed in a thermocycler ABI 9700 (Applied Biosystems $^{\mathrm{TM}}$, USA) with the use of thermostable polymerase OptiTaq (EURx, Poland). Subsequently, PCR products were purified using the ExoSAP-IT PCR Product Cleanup Kit (Affymetrix, Inc., USA). Direct sequencing of PCR products was performed using 341F (5-CCTACGGGAGGCAGCAG3), 518R (5-GTATTACCGCGGCTGCTGG-3), and 928F (5TAAAACTYAAAKGAATTGACGGG-3) primers, BigDye Terminator Mix v3.1 and genetic analyzer ABI3730xl (Applied Biosystems ${ }^{\mathrm{TM}}$, USA). From obtained sequences, it was assembled the contig and then consensus sequences were compared with known $16 \mathrm{~S}$ rDNA genes at the National Center for Biotechnology Information (NCBI) BLAST database (Altschul et al. 1997). Obtained sequence was submitted to GenBank, and it was received the accession number. 


\section{Identification of the isolated bacteria by intact cell MALDI-TOF MS}

The matrices HCCA $(10 \mathrm{mg} / \mathrm{mL})$ was prepared in bacterial solution $(\mathrm{EtOH} / \mathrm{ACN} / \mathrm{H} 2 \mathrm{O}, 1: 1: 1(v / v / v))$. The trifluoroacetic acid (TFA) solution was added to Bacterial Solution with $2.5 \% v / v$ of the final concentrations. Then, under sterile conditions, two lapfuls of bacterial cells were suspended in $5 \mu \mathrm{L}$ of bacterial solution and thoroughly vortexed for $30 \mathrm{~s}$. Two microliters of bacterial suspension was mixed with $2 \mu \mathrm{L}$ of the matrix, and then $1 \mu \mathrm{L}$ of the mixture was overlaid on the ground steel MALDI target. After $30 \mathrm{~min}$, when all spots had dried, the target was placed in the ultrafleXtreme MALDI-TOF/TOF mass spectrometer for measurement according to Pomastowski et al. (2015). The ultrafleXtreme MALDI-TOF/TOF mass spectrometer is equipped with a modified neodymium-doped yttrium aluminum garnet (Nd:YAG) laser (Smartbeam IITM) operating at the wavelength of $355 \mathrm{~nm}$ and the frequency of $2 \mathrm{kHz}$. IC MALDITOF MS spectra were recorded manually in linear positive mode within $\mathrm{m} / \mathrm{z}$ range of 300-30,000 and applying the acceleration voltage of $25 \mathrm{kV}$. All the mass spectra were acquired and processed with the dedicated software: flexControl and flexAnalysis, respectively (both from Bruker).

\section{Synthesis of LCLB56-AgCs}

For synthesis of the silver composites, $250 \mathrm{~mL}$ MH broth was prepared in a flask, sterilized and inoculated with a fresh culture of LCLB56 strain. The inoculate was transferred to bioreactor Biostat A (Sartorius Stedim Biotech, Germany) and incubated (100 rpm) with $\mathrm{MH}$ medium at $26{ }^{\circ} \mathrm{C}$ for 5 days. Then, the culture was centrifuged at $9000 \mathrm{rpm}$ for $15 \mathrm{~min}$, the supernatant was combined with $1 \mathrm{mM} \mathrm{AgNO}$ (final concentration) and incubated at $26^{\circ} \mathrm{C}$ in a shaker for 7 days in the dark. Bioactive composites were centrifuged at $14,000 \mathrm{rpm}$ for $30 \mathrm{~min}$ to concentrate. Then, unreacted silver ions and low molecular weight metabolites were removed by a 3-day dialysis ( $3 \mathrm{kDa}$ cutoff, Spectrum Lab, USA). MH broth mixed with $1 \mathrm{mM} \mathrm{AgNO}_{3}$ (final concentration) was used as a control sample.

\section{Characteristics of synthesized LCLB56 biosilver composites}

\section{$D L S$ and $Z P$}

The size and zeta potential measurements of LCLB56-AgCs were performed using Zetasizer Nano Series (Malvern Instruments, Great Britain). Size distribution analysis was measured by the dynamic light scattering methods. First, the BioAgCs was suspended in a $0.87 \% \mathrm{KCl}$ solution at $\mathrm{pH} 5-7$; then, the solution was sonicated for $20 \mathrm{~min}$ and vortexed directly before measurements. It was used UV-grade cuvettes for size measurements and folded capillary cells for zeta potential determination. All measurements were analyzed in triplicate.

\section{FTIR analysis}

FTIR analysis of surfaced functional groups in organics part of silver biocolloids has been performed. The samples were dried at $37^{\circ} \mathrm{C}$ to remove the water. The infrared spectrum was registered three times in MIR range (FTIR Genesis II Mattson, USA) using the pellet method in $\mathrm{KBr}$. Spectroscopic data were processed using WINFIRST software. The sample of obtained silver composites was also suspended in $0.09 \% \mathrm{NaCl}$ at pH 4.7 and 10. The FTIR spectra were registered in range of $1350-1870 / \mathrm{cm}$ using thin layer method in DirectDetect ${ }^{\circledR}$ Infrared Spectrometer (Merck Millipore, Germany).

\section{Electron microscopy and X-ray diffraction study}

The size of synthesized LCLB56-AgCs size was measured using transmission electron microscopy (TEM, FEI Tecnai F20 X-Twin) and scanning electron microscopy (SEM, LEO 1430VP) in tandem with EDX detector (XFlash 4010, Bruker AXS). A sample solution was applied to a carbon-coated copper grid. Then, the sample was subjected to drying. X-ray analysis diffraction (XRD) was used for determination and characterization of the crystal structure. The LCLB56-AgCs sample was deposited onto the glass slide and then recorded by X-ray diffractometer (X'Pert Pro Analytical Phillips) equipped with $\mathrm{Ni}$ filter and $\mathrm{Cu} \mathrm{K} \alpha(\lambda=1.54056 \AA)$ radiation source.

\section{Fluorescence spectroscopy}

Fluorescence spectra were obtained with a spectrofluorometer Jasco FP-XX (Japan). Samples $0.12 \mathrm{mg}$ and $1.2 \mathrm{mg}$ of silver nanocomposites were suspended in $1 \mathrm{~mL}$ of deionized water, sonicated for $5 \mathrm{~min}$, and positioned in a quartz cuvette with a $1-\mathrm{cm}$ path length. Three-dimensional (3D) excitation-emission spectra were recorded with $1 \mathrm{~nm}$ wavelength intervals in range $250-585 \mathrm{~nm}$ and 260 $600 \mathrm{~nm}$, respectively.

\section{MALDI-TOF/TOF MS analysis}

All chemicals for the MALDI MS analyses were supplied at the highest commercially available purity by Fluka Feinchemikalien (Neu-Ulm, Germany; a subsidiary of Sigma-Aldrich). Ground steel targets (Bruker Daltonik, Bremen, Germany) were used for sample deposition. The $\alpha$-cyano-4-hydroxycinnamic acid (HCCA) was employed as matrix for MALDI analysis of biosilver spotted by dried 
droplet method (Pomastowski et al. 2015). Protein Calibration Standards I (Bruker Daltoniks, Bremen) and HCCA were used for external calibration. All the MS spectra were obtained using the MALDI-TOF/TOF mass spectrometer (Bruker Daltonik, Bremen, Germany) equipped with a modified Nd:YAG laser operating at the wavelength of $355 \mathrm{~nm}$ and frequency of $2 \mathrm{kHz}$. The system was controlled using the Bruker Daltonik software (flexControl and flexAnalysis). Molecular fingerprint (MF) spectra of silver biocolloids were recorded in reflectron positive mode, within an $\mathrm{m} / \mathrm{z}$ range of 100-3500, and applying an acceleration voltage of $25 \mathrm{kV}$.

\section{Antimicrobial activity}

\section{MIC method}

The assay was performed according to Clinical and Laboratory Standards Institute (CLSI) guidelines. The final concentration of LCLB56-AgCs $(200,100,50,25,12.5$, 6.25 and $3.125 \mu \mathrm{g} / \mathrm{mL}$ ) was added to bacterial strains previously cultured on Mueller-Hinton broth $\left(1 \times 10^{6} \mathrm{CFU} / \mathrm{mL}\right)$. The plates were incubated for $18 \mathrm{~h}$ at $35^{\circ} \mathrm{C}$. Bacterial cells viability was read at $600 \mathrm{~nm}$ using BIOLOG multimode reader. Untreated bacterial materials served as control.

\section{Well-diffusion method}

Well diffusion method has been performed on MuellerHinton agar (MHA) plates. The silver composites (15, 7.5, and $1.875 \mu \mathrm{g} / \mathrm{well}$ ) were aseptically placed on the MHA surface inoculated with $100 \mu \mathrm{L}$ of $1 \times 10^{6}$ bacterial suspension. Plates were incubated at $35^{\circ} \mathrm{C}$ for $24 \mathrm{~h}$, and then the diameter of the inhibition zones was measured in $\mathrm{mm}$. All measurements were carried out in triplicates.

\section{Fluorescence microscopy assay}

The antimicrobial effect of LCLB56-AgCs was also observed microscopically against $S$. aureus using fluorescence dyes (acridine orange $(0.12 \mu \mathrm{g} / \mathrm{mL})$ and ethidium bromide $(0.4 \mu \mathrm{g} /$ $\mathrm{mL}$ ) in order to visualize living and dead cells. Viability of cells exposure to different doses $(12.5$ and $100 \mu \mathrm{g} / \mathrm{mL})$ of silver composites was detected through the filter set to 43 He and 38 using Zeiss Axiocom D1 fluorescence microscope. LCLB56-AgCs was added to cell culture media $\left(1 \times 10^{6}\right.$ of cells) and then analyzed after 3 and $24 \mathrm{~h}$ of incubation. Stained treated cells were incubated at room temperature for $5 \mathrm{~min}$ in the dark, centrifuged at $4000 \mathrm{rpm}$ for $5 \mathrm{~min}$, and then the supernatant was discarded to eliminate the unbound dyes. The remaining cell pellet was resuspended in sterile phosphate-buffered saline. The cells untreated with silver composites served as control.
Cytotoxicity assay

To determine cell viability after treatment with silver biocomposites, the colorimetric MTT metabolic activity was used. L929 cells $\left(1 \times 10^{4}\right.$ cells/well $)$ were chosen to study cytotoxic potential as ISO 10993-5 recommends. L-929 fibroblast cells were grown in DMEM with $2 \mathrm{mM}$ glutamine and $10 \%$ fetal bovine serum (FBS) in a 96 -well plate at $37^{\circ} \mathrm{C}$ and exposed to varying concentrations of LCLB56-AgCs (12.5$200 \mu \mathrm{g} / \mathrm{mL}$ ) for 24 and $48 \mathrm{~h}$, respectively. The cells untreated with silver composites served as negative control. Then MTT solution was added to the final concentration $0.2 \mathrm{mg} / \mathrm{mL}$. After $3.5 \mathrm{~h}$ of incubation at $37^{\circ} \mathrm{C}$, media were carefully removed and DMSO was added. Samples were agitated on orbital shaker for $15 \mathrm{~min}$. The absorbance was read at $590 \mathrm{~nm}$ by a microplate reader. All experiments were performed in triplicate, and the relative cell viability (\%) was expressed as a percentage of untreated control cells. Concentration of LCLB56-AgCs showing a 50\% reduction in cell viability (i.e., IC50 values) was calculated.

Nucleotide sequence accession number The nucleotide sequences of $16 \mathrm{~S}$ rDNA L. lactis 56 has been submitted in GenBank with accession numbers KY484989 and deposited in the Polish Collection of Microorganisms (PCM) under deposit no. B/00116.

\section{Results}

\section{Identification of the LAB strain isolated from milk}

The obtained results after 16S rDNA sequencing of LAB strain investigated in this study was identified as L. lactis 56 [KY484989] with 100\% (1469/1469) sequence overlap with the most similar L. lactis NCDO 604 [NR_040955] (Fig. 1a). Moreover, the acquired spectra for $L$. lactis 56 were compared with MALDI spectra of reference bacterial strains ( $L$. lactis ATCC 49032). 99-100\% of cover was obtained Fig. 1 b.

\section{Electron microscopy and X-ray diffraction study}

EDX spectrum shows a signals in range of $2.7-3.2 \mathrm{keV}$ confirms the presence of metal silver and binding energies of biocompounds on the surface of the Ag-NCs. (Fig. 2a). The other small peaks correspond to elemental carbon, oxygen, sodium, magnesium and chloride related with the presence of organics part and remains of the medium onto silver nanoparticle surface. TEM analysis revealed the presence of many spherical in shape nanoparticles with size of 5-50 nm. Their average diameter was $19 \pm 2 \mathrm{~nm}$. A high-resolution TEM image showed interference fringe patterns with interplanar distances $0.228 \mathrm{~nm}$ characteristic for silver (Fig. 2b, c). The selected area 
Fig. 1 a Phylogenetic relationships of Lactococcus lactis 56 strain. Neighbor-joining analysis of $16 \mathrm{~S}$ rDNA sequences, using the number of differences method (Nei and Kumar 2000) combined with bootstrap analysis from 1000 replicates (bootstrap values $<50 \%$ not shown). All positions containing gaps and missing data were eliminated. There were a total of 1440 positions in the final dataset. Analyses were performed using MEGA7 software (Kumar et al. 2016). b The confirmation spectrum of L. lactis 56 performed using the MALDITOF MS technique on HCCA matrix
A

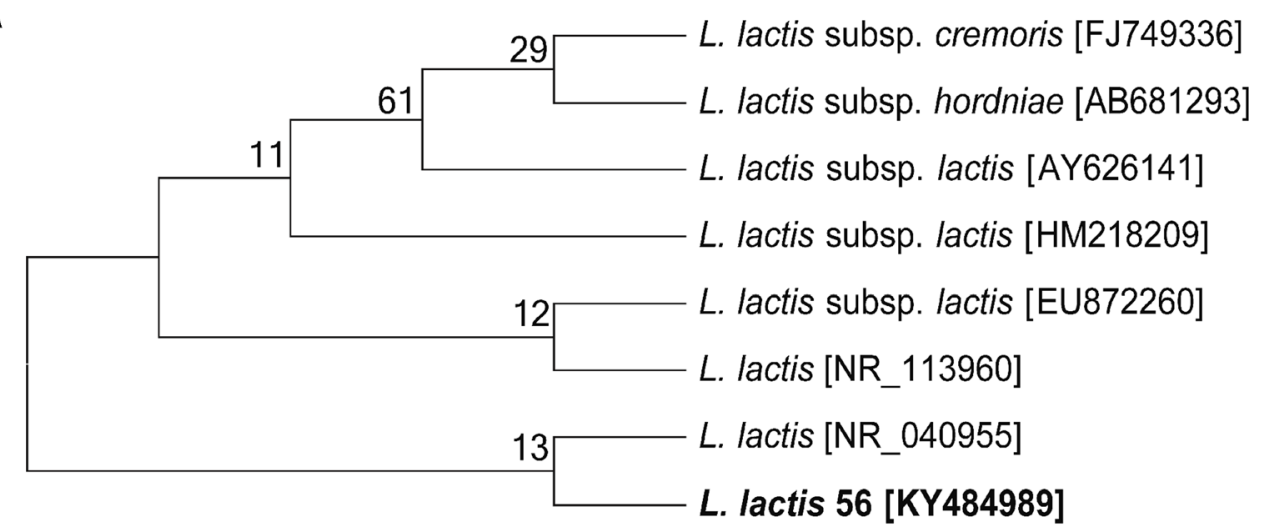

B

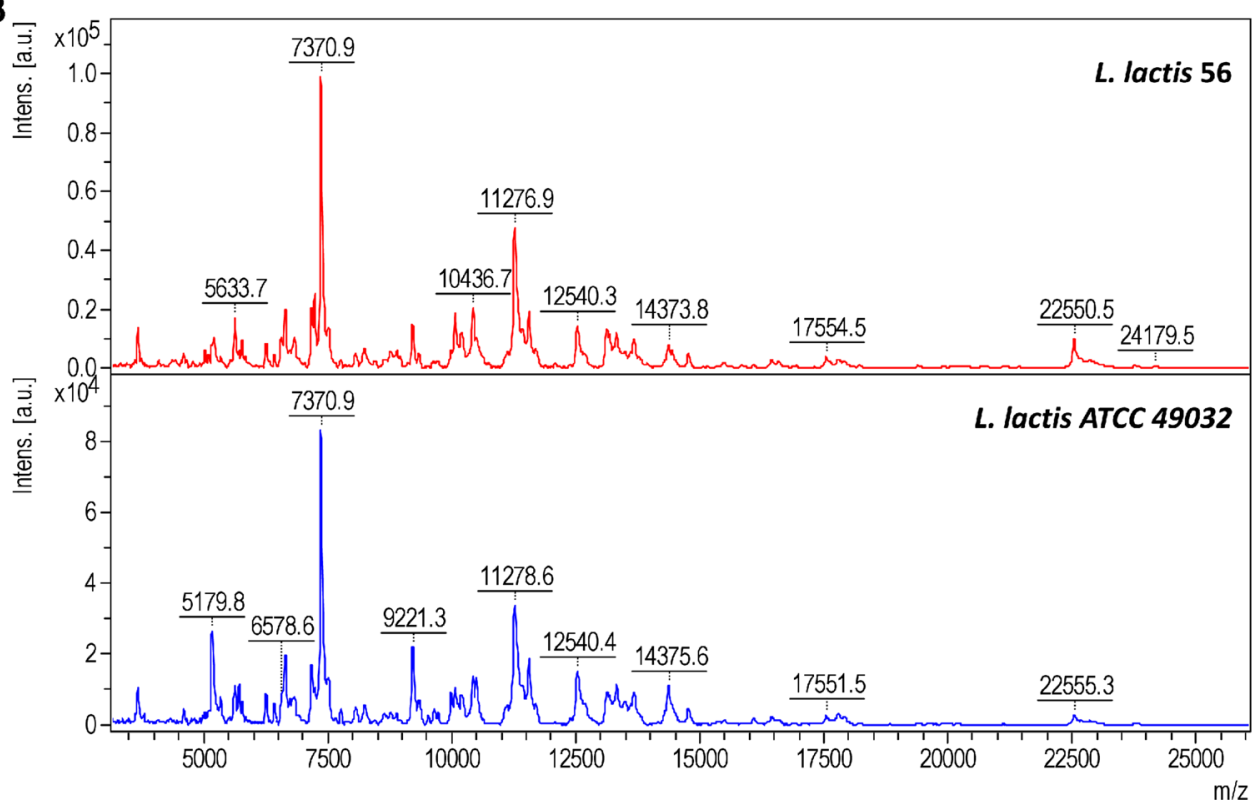

diffraction pattern (SAED) confirmed highly crystalline nature of synthesized nanoparticles. Figure $2 \mathrm{~d}$ shows concentric rings which can be assigned to the diffraction planes (111), (200), (220), and (311) characteristic for metallic silver.

Figure 2e shows X-ray analysis diffraction (XRD) pattern of silver composites deposited on a glass slide. Results confirm that the silver particles formed in our experiments are in form of nanocrystals. Typical peaks were present at $2 \theta=38.08^{\circ}, 44.34^{\circ}, 64.43^{\circ}$, and $77.41^{\circ}$ which corresponds to (111), (200), (220), and (311) Bragg reflections characteristic for silver. Full width at half maximum $(\beta)$ of the first peak measured in XPert High Score program was 0.3103. Hence, the size of silver nanoparticles calculated according to DebyeScherrer equation was approximately $27.18 \mathrm{~nm}$. The DebyeScherrer used formula was

$D=\frac{K \lambda}{\beta \cos \theta}$

$D$ - crystallite size; $\boldsymbol{\lambda}$ - the wavelength of the X-ray source $(0.15418 \mathrm{~nm}) ; \boldsymbol{\beta}$ - the full width at half maximum of the diffraction peak; $\boldsymbol{K}$-Scherrer constant with a value from 0.9 to $1 ; \boldsymbol{\theta}$-Bragg's diffraction angle.

\section{FTIR}

Spectroscopic study in infrared range $1800-500 / \mathrm{cm}$ was illustrated to identified functional groups of compounds localized in organics deposit of the silver biocolloids. Figure 3a illustrates FTIR spectra of dried biosilver composites in $\mathrm{KBr}$ disc. The absorption bands at $1650 / \mathrm{cm}$ are a consequence of the presence of amide I vibrations arisen mainly from the $\mathrm{C}=\mathrm{O}$ stretching vibration, whereas amide II region $(\mathrm{N}-\mathrm{H}$ bending and C-N stretching) occurred at 1550/cm (Haris and Severcan 1999). The spectral bands at $1650 / \mathrm{cm}$ (Fig. 3b) can indicate at symmetric stretching vibration from arginine residues $\left(\mathrm{CN}_{3} \mathrm{H}_{5}{ }^{+}\right)$(Sreeprasad et al. 2011). This amino acid constitutes the active carboxyl groups, and the FTIR spectra (Fig. $3 b)$ suggest that it is involved in the ionization processes of organics part at pH range 4-10 (Haris and Severcan 1999; Sreeprasad et al. 2011). Moreover, change in spectrum band at range $1560 / \mathrm{cm}$ (Fig. 3b) indicates the presence of glutamic 


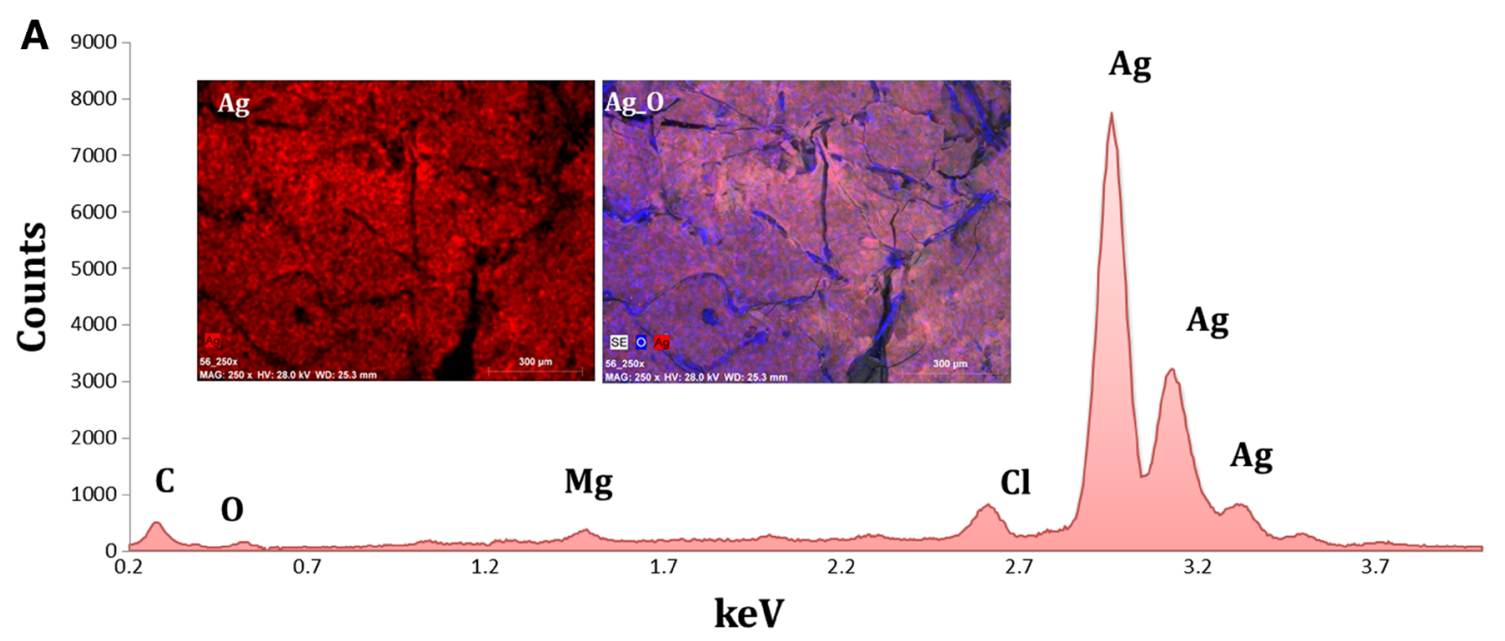

B

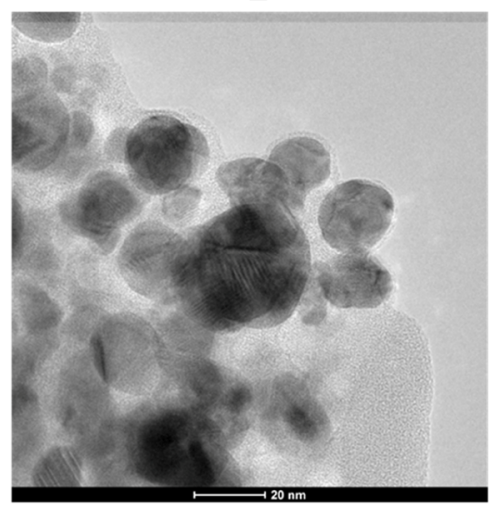

C

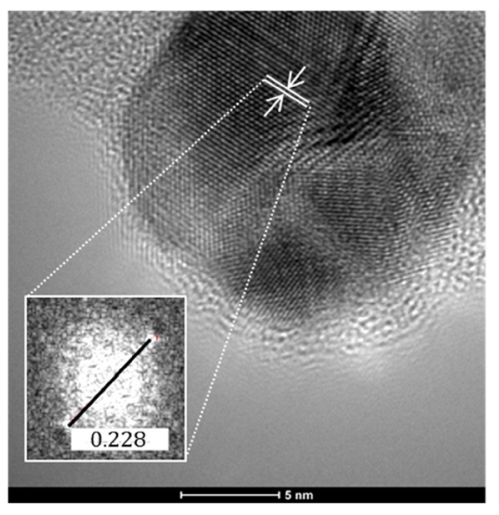

D

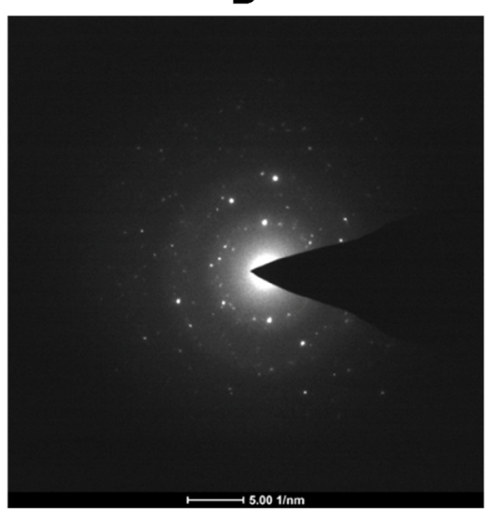

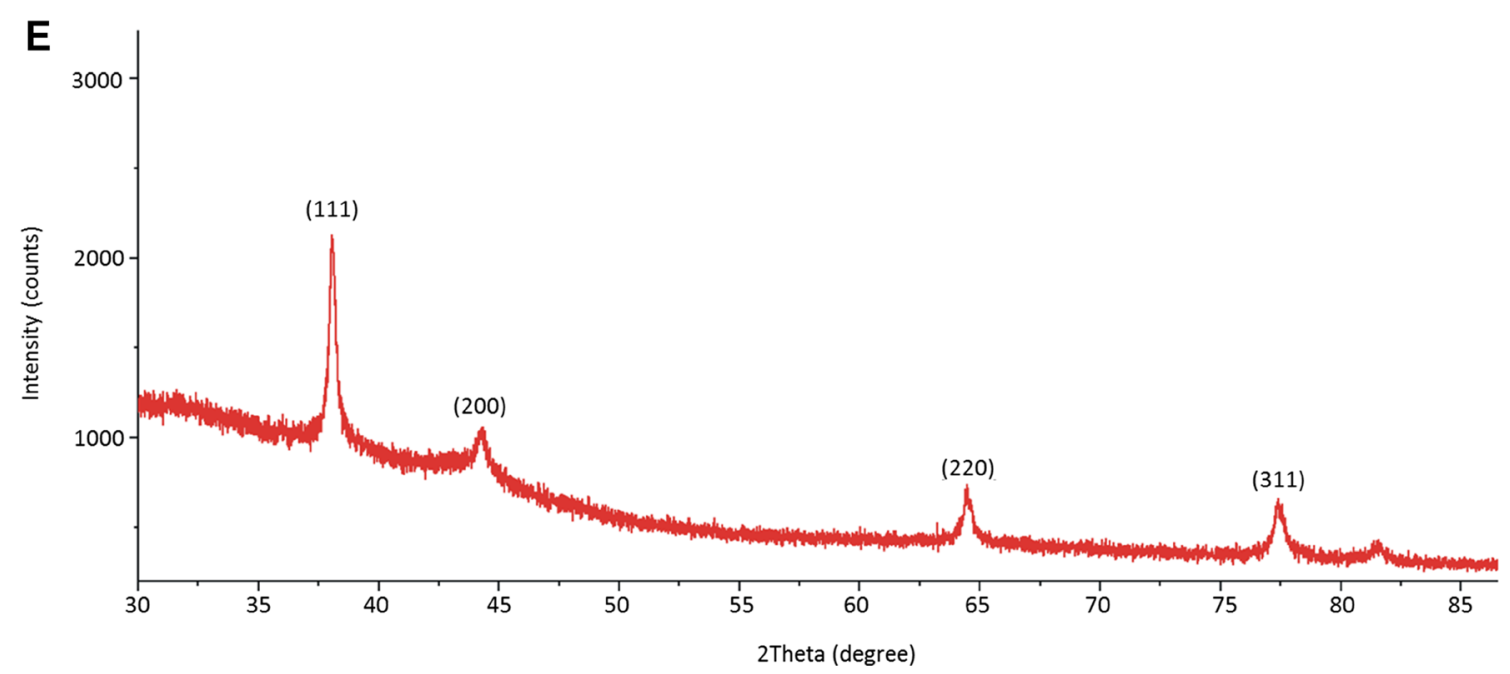

Fig. 2 EDX spectra of a LCLB56-AgNCs (a), TEM micrograph (b), and FFT image (c); SAED (d) and XRD (e) patterns of bioactive silver nanoparticles

and aspartic acid $\left(-\mathrm{COO}^{-}\right)$in colloids structure. The bands at 1560/cm (Fig. 3a, b) originate from deprotonated carboxyl groups and indicate participation of acid amino acid such as glutamic and aspartic acids in the structure of organics deposit of silver biocolloids (Sreeprasad et al. 2011). The absorption peaks localized at 1560 (Fig. 3a, b) are also related to amide II vibrations (Sreeprasad et al. 2011). The spectral band at 1470/cm (Fig. 3a, b) could originate from in plane bending of methylene $\left(-\mathrm{CH}_{2}\right)$ group. Finally, this band is characteristic for His ${ }^{-}$as well as bending from methyl $\left(\mathrm{CH}_{3}\right)$ group and stretching from $\mathrm{CN}$ group (Sreeprasad et al. 2011). The $\mathrm{pKa}$ value of imidazole group is 6 . Therefore, the change at spectra 
Fig. 3 Infrared spectrum of LCLB56-AgNCs registered in MIR range (a) and using thin layer method in DirectDetect ${ }^{\circledR}$ Infrared Spectrometer (b)
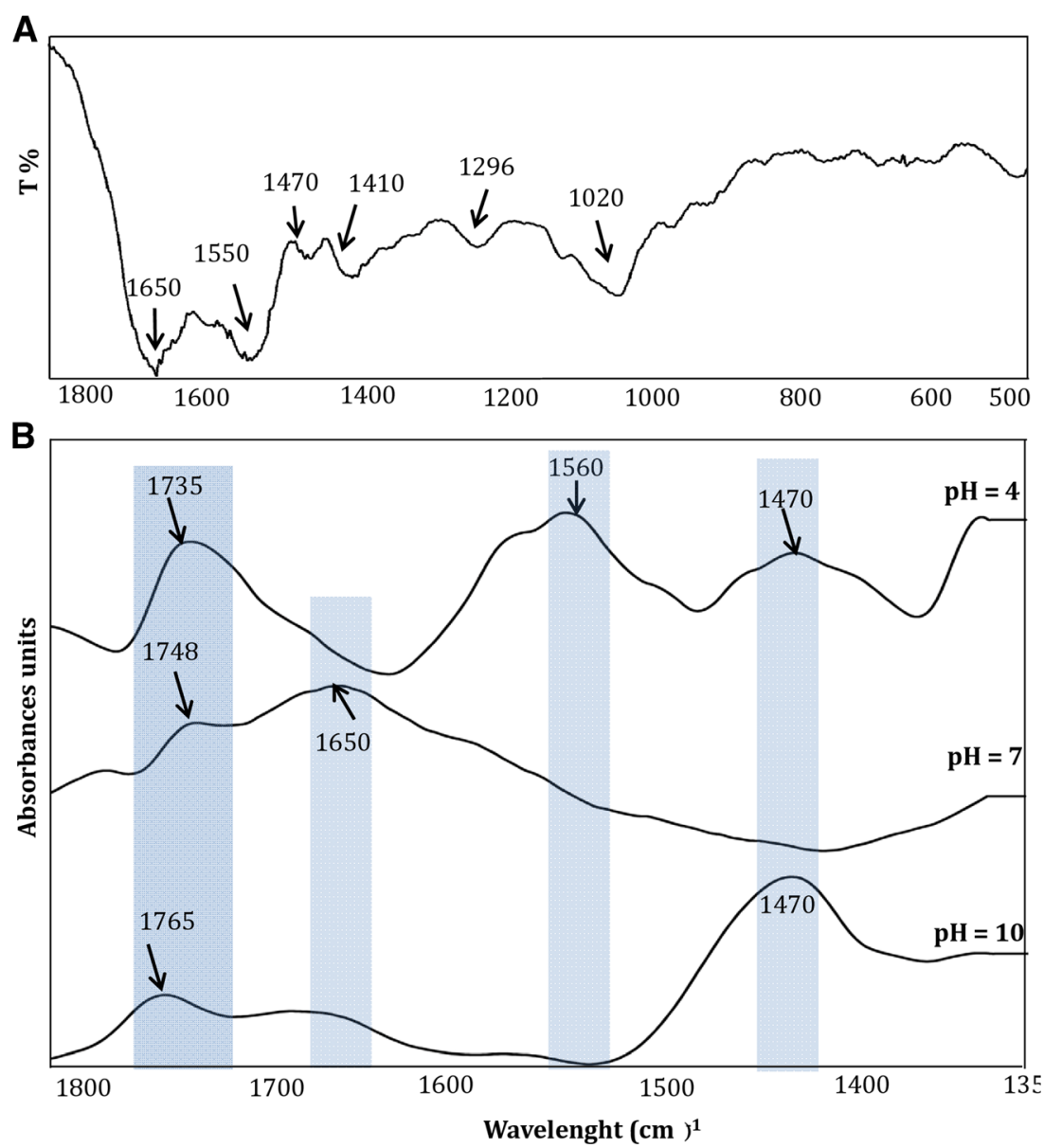

range could indicate the presence of phenolic ring and deprotonation processed depends on $\mathrm{pH}$ of solvents (Fig. 3b). The band at 1410 and 1020/cm (Fig. 3a) corresponds to bending vibration of hydroxyl groups $v(\mathrm{OH})$ and $\mathrm{C}-\mathrm{O}-\mathrm{C}$ vibration band of lactic acid, respectively. The absorption band at 1296/ $\mathrm{cm}$ (Fig. 3a) originates from carbonyl $(-\mathrm{C}=\mathrm{O})$ banding vibration of lactic acid and its metabolites (Vodnar et al. 2010). The shift of absorption band at 1735, 1748, and 1765/cm indicates on present $\mathrm{C}=\mathrm{O}$ stretching vibrations of fatty acids or lipids (Sreeprasad et al. 2011). The change in spectra (Fig. 3b) results from $\mathrm{pH}$-dependent reaction of carboxyl groups. The band in range of $800-600 / \mathrm{cm}$ (Fig. 3a) is characterized by $\mathrm{C}-\mathrm{H}$ vibrations of proteins, peptides, amino acids, or lipids in organic deposit (Sreeprasad et al. 2011).

\section{Fluorescence spectroscopy}

The 3D profiles (Fig. 4) of silver nanocomposites were recorded to determine the fluorescence nature of synthesized biocolloids. There were observed three main groups of florescence bands. The most intensive fluorescence band was measured at excitation and emission wavelengths of 270 and $540 \mathrm{~nm}$, respectively. It is caused by florescence of quartz consist of the cuvette, used for fluorescence assay. In contrast to negative control (water) it was observed the increase of florescence intensity in case of suspension of silver nanocomposites. Moreover, the registered bands at excitation and emission wavelengths were of 480 and $493 \mathrm{~nm}$ and 280 and $320 \mathrm{~nm}$, respectively (Fig. 4). Furthermore, in was measured the fluorescence of silver nanocomposites in two different concentrations. In case of silver nanocomposites at concentration $0.12 \mathrm{mg} / \mathrm{mL}$, the fluorescence intensity of all three bands was at the similar level in comparison to silver nanocomposites at concentration $1.2 \mathrm{mg} / \mathrm{mL}$.

\section{Matrix-assisted laser desorption ionization-time of flight mass spectrometry}

Spectrometric matrix-assisted laser desorption ionizationtime of flight (MALDI-TOF MS) analysis was performed to illustrate the presence of silver isotopes, silver-organic connections and clusters of silver in analyzed sample of silver biocomposites. Figure 5a illustrates molecular fingerprint of synthesized silver biocolloids, registered in refection and positive mode. To avoid the false positive results, HCCA matrix with spotted $1 \mathrm{mM}$ silver nitrate was used as a control (V) (Fig. 5b). Many of matrix signals are present in LCLB56, e.g., $m / z, 190.050$ origin from ionized HCCA matrix $[\mathrm{HCCA}+\mathrm{H}]^{+}$, but $m / z 379.092$ (yellow stripe) results from ionized dimer of matrix $[2 \mathrm{HCCA}+\mathrm{H}]^{+}$(Hendrik et al. 2004). Signals $\mathrm{m} / \mathrm{z}$ 
Fig. 4 Fluorescence of LCLB56AgNCs nanocomposites

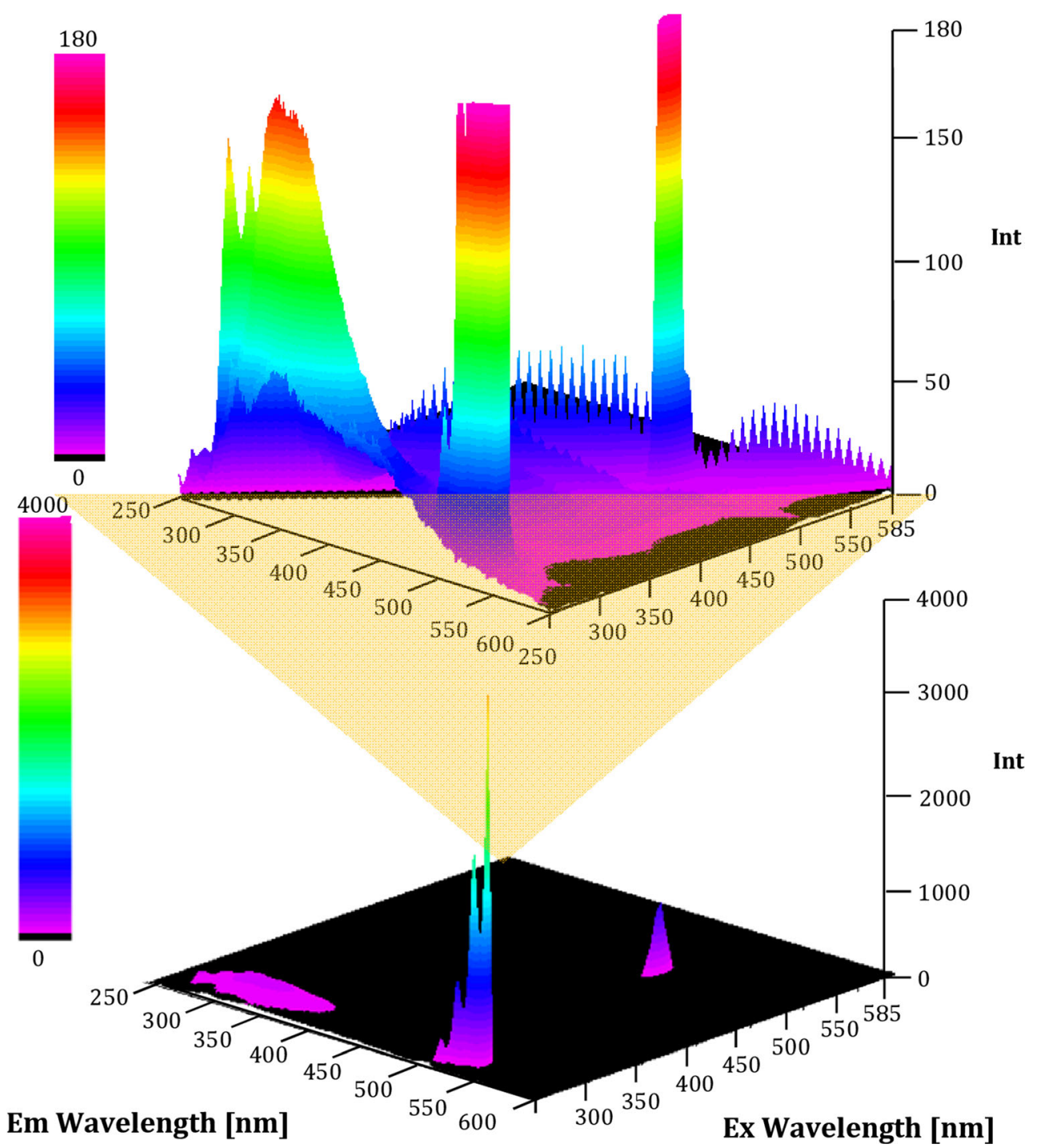

527.097, 1043.480, 1057.469, 1073.405, and 1150.130 are characteristic for ionized peptides $[\mathrm{P}-\mathrm{H}]^{+}$. Peptides consist of the arginine, glutamine acid or aromatics rings (e.g., tryptophan, tyrosine) easily ionized. MALDI measurements have shown the presence of lactic acid (LA) dimer $\mathrm{m} / \mathrm{z}, 182.846$ $[2 \mathrm{LA}+\mathrm{H}]^{+}$and its metabolites: dehydrated $(\mathrm{m} / \mathrm{z}-18) \mathrm{m} / \mathrm{z}$ $164.854[2 \mathrm{LA}-\mathrm{HOH}+\mathrm{H}]^{+}$and the decarboxylate $(\mathrm{m} / \mathrm{z}-44)$ $\mathrm{m} / \mathrm{z} 138.850[2 \mathrm{LA}-\mathrm{COO}+\mathrm{H}]^{+}$dimer of LA.

\section{Antimicrobial activity assay}

LCLB56-AgNCs exerted an inhibitory effect against all tested bacterial strains (P. aeruginosa ATCC10145, P. mirabilis ATCC25933, S. epidermidis ATCC49461, MSSA ATCC29213 and $S$. aureus ATCC6338). The effectiveness (inhibition zones) of LCLB56-AgCs provided by well diffusion method is shown in Fig. 6. More pronounced antimicrobial effect was noticed for $15 \mu \mathrm{g} /$ well in comparison with 7.5 and $1.875 \mu \mathrm{g} /$ well (Table 1). As shown in Table 2, $\mathrm{MIC}_{90}$ of synthesized LCLB56-AgCs was in a range of 3.125-12.5 $\mu \mathrm{g}$ / mL. S. aureus, S. epidermidis, and P. mirabilis were especially susceptible to LCLB56-AgCs treatment at the lowest concentration $3.125 \mu \mathrm{g} / \mathrm{mL}$. For $P$. aeruginosa, concentration of $6.25 \mu \mathrm{g} / \mathrm{mL}$ was enough to completely inhibit its growth. The $\mathrm{MIC}_{90}$ toward MSSA strain was found at $12.5 \mu \mathrm{g} / \mathrm{mL}$ concentration. Less inhibitory effect was observed against $S$. aureus in case of highest concentration of LCLB56-AgCs $(200 \mu \mathrm{g} / \mathrm{mL})$ with the viability of cells about $70 \%$. Similarly in case of $100 \mu \mathrm{g} / \mathrm{mL}$ concentration, cell viability was reduced to $40 \%$. Moreover, those results are in agreement with results from fluorescence microscopy assay when the amount of total cells increase considerably compared to control after 3 and $24 \mathrm{~h}$ of incubation (Fig. 7). Furthermore, small agglomeration was observed for the cells treated with $100 \mu \mathrm{g} / \mathrm{mL}$. However, the number of dead cells (red) increased considerably for incubation lasting $24 \mathrm{~h}$. The high concentrations of BioAgCs are more susceptible to aggregation in some cases, thus triggering decreases in antimicrobial properties. 


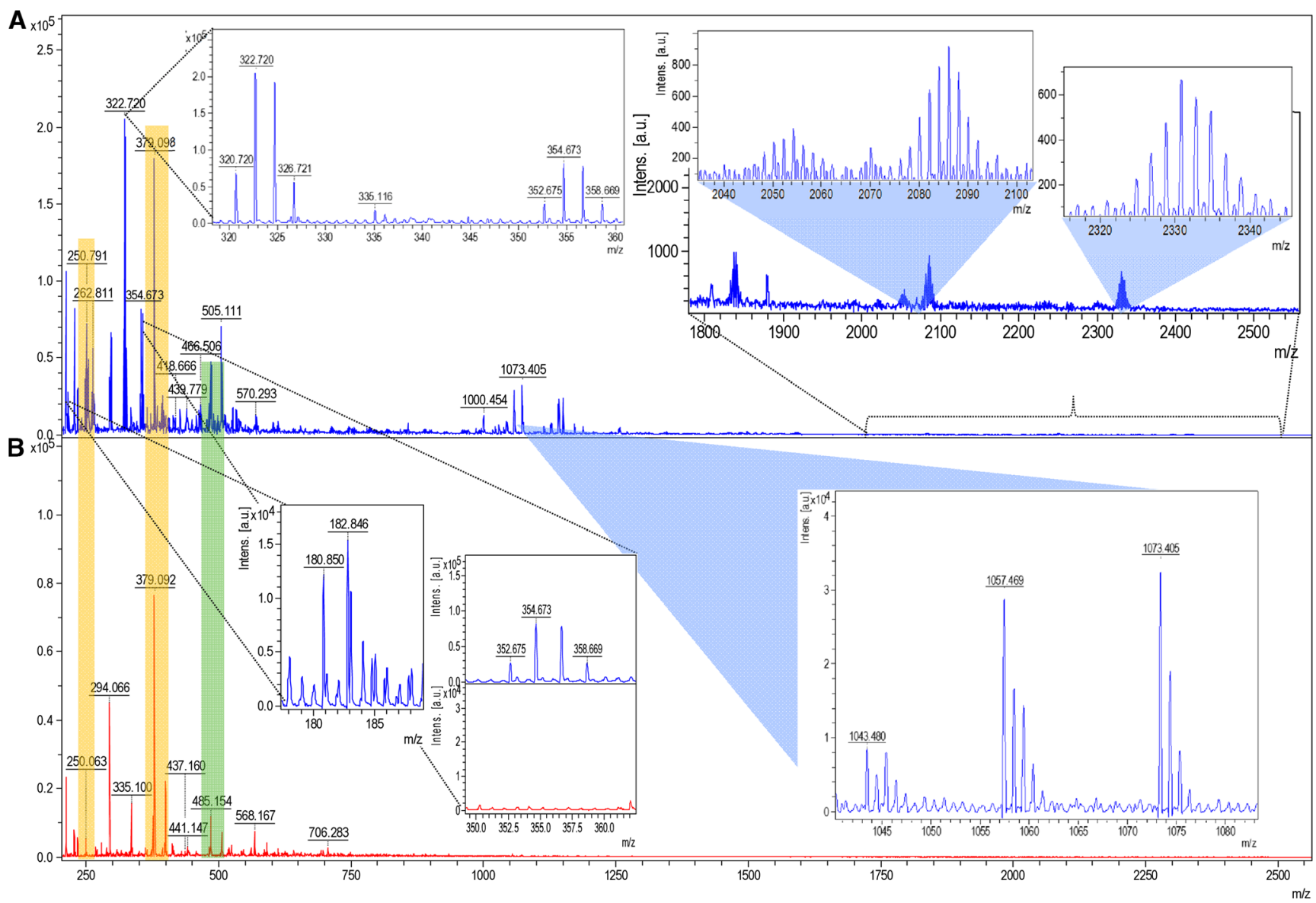

Fig. 5 Molecular fingerprint of synthesized LCLB56-Ag biocolloids (a) using MALDI-TOF MS technique and HCCA matrix with spotted $1 \mathrm{mM}$ silver nitrate as control (b)

Fig. 6 The inhibition zones of LCLB56-AgNPs provided by well diffusion method against a MSSA, b Staphylococcus aureus, c Proteus mirabilis, d

Pseudomonas aeruginosa, $\mathbf{e}$ Staphylococcus epidermidis
A

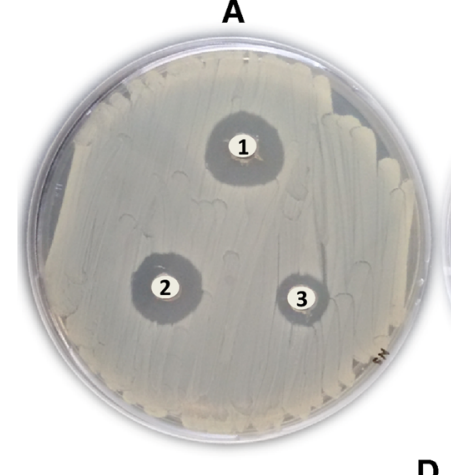

D

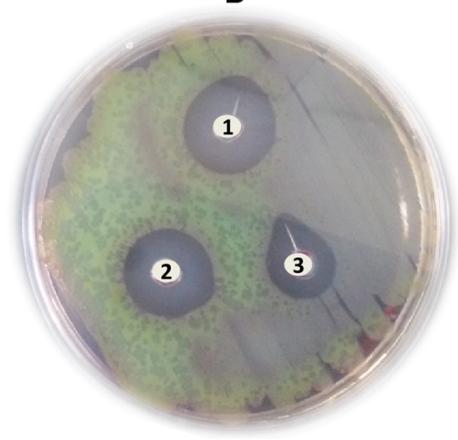

B

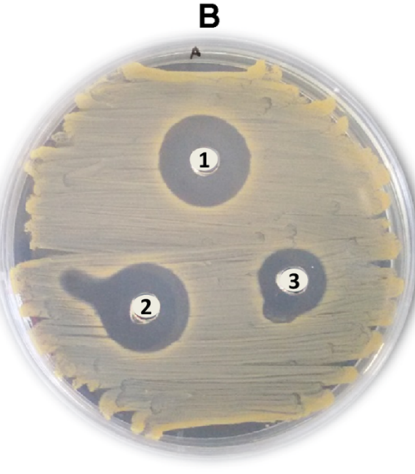

E

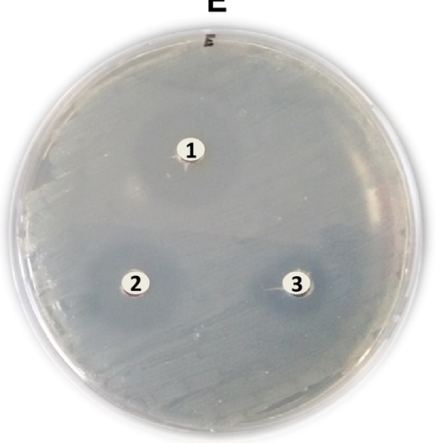


Table 1 Antibacterial activities of different concentrations LCLB56

\begin{tabular}{llll}
\hline Bacterial cells & \multicolumn{2}{l}{ Mean zone of inhibition [mm] } \\
\cline { 2 - 4 } & $15 \mu \mathrm{g} / \mathrm{mL}(1)$ & $7.5 \mu \mathrm{g} / \mathrm{mL}(2)$ & $1.875 \mu \mathrm{g} / \mathrm{mL}(3)$ \\
\hline Pseudomonas aeruginosa & $14 \pm 0.12$ & $12 \pm 0.06$ & $7 \pm 0.05$ \\
MSSA & $12 \pm 0.02$ & $9 \pm 0.05$ & $6 \pm 0.05$ \\
Staphylococcus aureus & $14 \pm 0.02$ & $12 \pm 0.09$ & $7 \pm 0.06$ \\
Staphylococcus epidermidis & $16 \pm 0.05$ & $12 \pm 0.08$ & $8 \pm 0.04$ \\
Proteus mirabilis & $11 \pm 0.07$ & $9 \pm 0.09$ & $6 \pm 0.02$ \\
\hline
\end{tabular}

\section{Cytotoxicity study}

The in vitro cytotoxic activity of LCLB56-AgCs against mouse fibroblast cell line L929 was measured by using MTT assay. After $24 \mathrm{~h}$ of incubation with LCLB56-AgCs changes in cell viability were not noticed (data not shown). Only $48 \mathrm{~h}$ incubation leads to a reduction in cell viability. The silver composites synthesized by $L$. lactis were able to reduce viability of the L929 in a dose-dependent manner as shown in Fig. 8. For comparison, we performed the same experiment for silver biocolloids synthesized by Actinomycete CGG 11n (Railean-Plugaru et al. 2016). The highest used concentration of LCLB56-AgCs $(200 \mu \mathrm{g} / \mathrm{mL})$ reduced cell viability to $67 \%$, whereas CGG11n to $44 \%$. At $25 \mu \mathrm{g} / \mathrm{mL}$ concentration, the viability of cells was 89 and $65 \%$, respectively. The concentration at which the cells viability was reduced to $50 \%$ for L929 cells was above $200 \mu \mathrm{g} / \mathrm{mL}$ for LCLB56-AgCs and $157 \mu \mathrm{g} / \mathrm{mL}$ for CGG $11 \mathrm{n}$. However, it is worth noting that in the case of CGG11n the reduction of cell viability is not linear and lower concentration $(25 \mu \mathrm{g} / \mathrm{mL})$ exhibited slightly higher cytotoxicity than higher concentration $(50 \mu \mathrm{g} / \mathrm{mL})$.

\section{Discussions}

Silver as a disinfectant has been known for centuries. Current environmental problems encourage researchers to search an inexpensive and more accessible safe source for synthesis of silver nanoparticles. L. lactis 56 is an alternative for this scope. Lactic acid bacteria are microorganisms isolated from different biological matrices, including raw milk, dairy products and fermented foods. In particular, samples of human and animal milk are habitats rich in nutrients and they are often used for isolation of a diverse spectrum of LAB (Martín et al. 2007; Carminati et al. 2014; Nejati et al. 2016). In our study, the identification of L. lactis was carried out by two different techniques, namely, 16S rRNA gene sequencing and intact cell MALDI-TOF MS. The first technique is commonly used for identification of LAB (Delgado et al. 2013; Neubeck et al. 2015). Recently, a growing interest of researchers in methods utilizing MALDI-TOF MS can be observed, because of its rapidity, repeatability, and precision. Currently, MALDI-TOF MS profiling of whole bacterial cells is being used more frequently for bacterial identification (Dec et al. 2014). Furthermore, based on shape of isotopic pattern of delectrons metals, it is possible to identify the organic compounds connected with these metals and clusters (Nicolardi et al. 2010). In this work, there were observed the signals of silver isotopes $\left[{ }^{107} \mathrm{Ag}\right]^{+} \mathrm{m} / \mathrm{z}, 106.905$ and $\left[{ }^{109} \mathrm{Ag}\right]^{+} \mathrm{m} / \mathrm{z}$ 108.910. The presence of silver ions in sample can result from laser induction of ionization processes in ion source. Many of released in ion source silver ions interact both with matrix and organics part of biocolloids. The signals $\mathrm{m} / \mathrm{z} 216.078$ and 485.154 (green stripe) originate from interaction of released silver ions with matrix $[\mathrm{HCCA}+\mathrm{Ag}]^{+}$and its dimer $[2 \mathrm{HCCA}+\mathrm{Ag}]^{+}$that are present in both sample and control
Table 2 Minimum inhibitory concentration of the LCLB56$\mathrm{AgCs}$ against various bacterial cells

\begin{tabular}{llllll}
\hline $\begin{array}{l}\text { Concentration } \\
(\mu \mathrm{g} / \mathrm{mL})\end{array}$ & $\begin{array}{l}\text { P. aeruginosa } \\
\text { Inhibitory effect by cells density }\end{array}$ & $\begin{array}{l}\text { S. aureus } \\
\text { c }\end{array}$ & & S. epidermidis & P. mirabilis \\
\hline 200 & $4.68 \pm 0.02$ & $70.21 \pm 0.03$ & $1.64 \pm 0.02$ & $4.46 \pm 0.01$ & $9.67 \pm 0.02$ \\
100 & $2.23 \pm 0.01$ & $40.42 \pm 0.02$ & $3.21 \pm 0.01$ & $4.59 \pm 0.02$ & $5.84 \pm 0.01$ \\
50 & $2.57 \pm 0.02$ & $1.29 \pm 0.01$ & $2.60 \pm 0.01$ & $5.30 \pm 0.02$ & $6.27 \pm 0.02$ \\
25 & $2.90 \pm 0.01$ & $0.60 \pm 0.03$ & $1.57 \pm 0.02$ & $4.85 \pm 0.03$ & $5.95 \pm 0.01$ \\
12.5 & $1.84 \pm 0.01$ & $2.54 \pm 0.01$ & $2.10 \pm 0.01$ & $4.20 \pm 0.01$ & $5.63 \pm 0.02$ \\
6.25 & $2.96 \pm 0.01$ & $3.86 \pm 0.01$ & $33.46 \pm 0.03$ & $3.75 \pm 0.01$ & $5.21 \pm 0.03$ \\
3.125 & $17.23 \pm 0.03$ & $5.90 \pm 0.01$ & $55.70 \pm 0.03$ & $4.20 \pm 0.02$ & $5.31 \pm 0.02$ \\
MIC $_{90}$ & 6.25 & 3.13 & 12.5 & 3.13 & 3.13 \\
\hline
\end{tabular}

The data is presented as the mean of three replicates 
Fig. 7 Fluorescence microscopy detection of living (greenlabeled) and dead (red-labeled) $S$. aureus cells after $3 \mathrm{~h}$ (a) and $24 \mathrm{~h}$ (b) of treatment with LCLB56-AgNPs $12.5 \mu \mathrm{g} / \mathrm{mL}$ and after $3 \mathrm{~h}(\mathbf{c})$ and $24 \mathrm{~h}(\mathbf{d})$ with $100 \mu \mathrm{g} / \mathrm{mL}$ (color figure online)
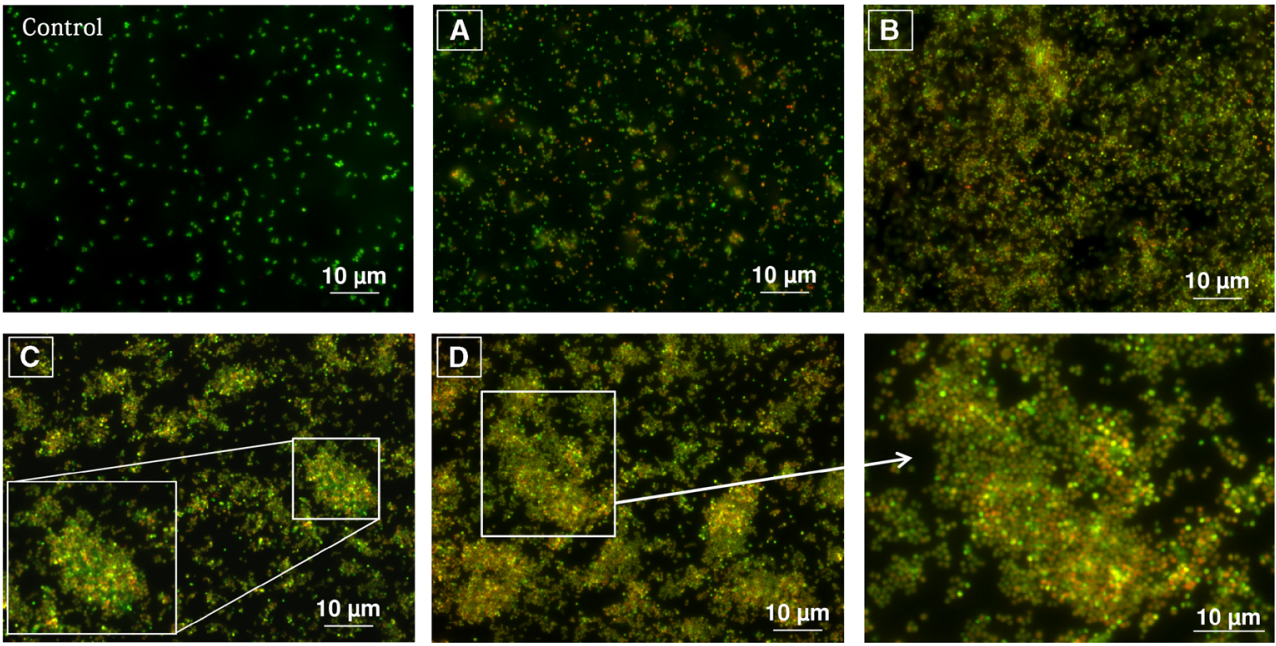

as well. Moreover, there were registered the clusters of silver $\left[\mathrm{Ag}_{x}+\text { Organics }+\mathrm{H}\right]^{+}$combined with organic compounds (absent in control sample): $\mathrm{m} / \mathrm{z} 322.720,354.673,2086.124$, 2579.282 , or 3285.183 . The presence of this signal suggests that, under laser treatment in ions source, the biocolloid system is destroyed to smaller pieces of silver cluster. Moreover, the obtained results confirm the presence of lactic acid, their metabolites and organic deposit connected with silver core of nanoparticles. In opposition to other previous unpublished results realized by our group, the presence of lactic acid and its metabolites in organic of LCLB56 suggests on higher saturation area of silver core and increases the capacity of binding secondary released silver ions.

The results obtained by MALDI technique are correlated with those from FTIR and fluorescence spectroscopy assay. The spectroscopic results proved the presence of active functional groups of organics part of silver biocolloids. The emission band obtained at $493 \mathrm{~nm}$ under excitation at $480 \mathrm{~nm}$ is the effect of light interaction with silver core of nanocomposites (Kun et al. 2015; Bharat et al. 2016; Jalaluddin et al. 2016). The fluorescence of silver nanocomposites has been proposed to explain fluorescence resonance energy transfer (FRET) process and electron transfer process by several mechanisms

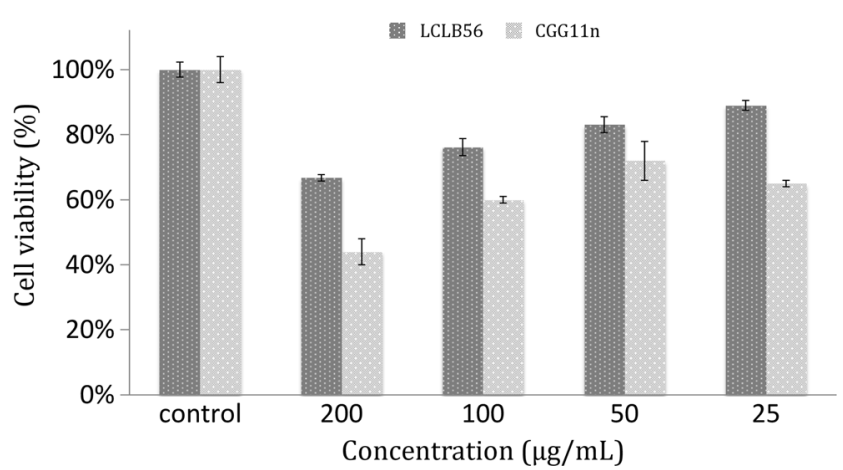

Fig. 8 Cytotoxicity effect of silver nanocomposites synthesized by Lactococcus lactis 56 including Purcell effects,(Kun et al. 2015; Bharat et al. 2016). Due to nanometer sizes, the silver biocolloids have a more discrete energy level as that of molecules, thus metal nanocomposites can still interact with incident light via electronic transitions between discrete energy levels, leading to strong light absorption and emission (Bharat et al. 2016; Jalaluddin et al. 2016). Furthermore, heterogeneity of silver biocolloids surface is extremely important for the optical properties of nanosystem. The interaction of surfaced ligands with silver core influence on charge-transfer process, dispersion stability, and high concentration of metal biocolloids, which results in quenching of florescence (Jalaluddin et al. 2016, Pomastowski et al. 2016). The emission band obtained at $320 \mathrm{~nm}$ under excitation at $280 \mathrm{~nm}$ is the effect of organics ligand present onto silver nanocomposites surface. Amino acids with aromatic side chains such as tyrosine, tryptophan, and phenylalanine under excitation of wavelengths in 280 $295 \mathrm{~nm}$ are fluorescent with high quantum yields (Innocent et al. 2009; Ammor et al. 2004; Jia et al. 2015).

Another proof of present organics part in silver biocolloids system was observed during mineralization - sample preparation stage for AAS determination of silver concentration in LCLB56. Obtained dark color of silver composites, under treatment of concentrated nitric $(\mathrm{V})$ acid, was changed to whiteyellow precipitate. Moreover, it was also observed the drastic increase of sample volume. This phenomena could be explained by well-known xanthoproteic reaction of protein, peptides - present in organics deposit of LCLB56 system (Chatterjea 2004). Furthermore, the formation of silver nanoparticles was confirmed by SEM and TEM with high productivity of the biosynthesis. The average amount of nanoparticles was $0.363 \pm 0.09 \mathrm{mg}$ from $50 \mathrm{~mL}$ of culture medium. The synthesis efficiency of synthesis varied from 71 to $85 \%$. The masses of dried nanoparticles vary from 1.23 to $0.95 \mathrm{mg}$ from $50 \mathrm{~mL}$ of culture medium. It indicates that $30-37 \%$ of biocolloids constitute the silver core and $70-63 \%$ organics part. 
Many studies proved the application of LAB-silver active as a strong antibacterial agent against pathogens (Shrivastava et al. 2007). This research showed effectiveness of LCLB56-AgCs against all tested Gram-positive (S. epidermidis ATCC49461, MSSA ATCC29213 and S. aureus ATCC6338) and Gramnegative ( $P$. aeruginosa ATCC10145, $P$. mirabilis ATCC25933) bacteria. Moreover, the minimum inhibitory concentration (MIC) of LCLB $56 \mathrm{AgCs}$ was relatively low against S. aureus $(3.12 \mu \mathrm{g} / \mathrm{mL})$, P. mirabilis $(3.12 \mu \mathrm{g} / \mathrm{mL})$ and P. aeruginosa $(6.25 \mu \mathrm{g} / \mathrm{mL})$ bacteria as compared to HGG16n_BioAgNPs and CGG 11n_BioAgNPs synthesized by Actinobacteria reported by our group in other research (Railean-Plugaru et al. 2016; Buszewski et al. 2016). Inhibitory effect of silver composites depends on the isolated strain. It seems that LCLB $56 \mathrm{AgCs}$ synthesized by L. lactis 56 is even more effective than silver biocolloids obtained by Actinobacteria strain. On the another hand, the effect of silver composites could results from higher dispersion of this solution. In this regard, high dispersion seems to create colloidal stability of the system, thus increasing the bioavailability of silver. Furthermore, the presence of different organic deposit connected with silver core of nanoparticles could influence the colloid stability, consequently effectiveness of bioactive silver composites.

Many studies indicate that bioactive silver possess adverse effects on alive eukaryotic cells. It is believed that silver particles could be toxic at cellular, subcellular, and biomolecular level (Dubey et al. 2015). Hence, the first step in application of AgNPs as antibacterial agent should be evaluation of the cytotoxicity. The results indicate that cytotoxicity of silver composites synthesized by L. lactis 56 depends on time and concentration. After 1 day of incubation, there were no signs of cytotoxicity. The value of IC 50 after 48 exposition was above $200 \mu \mathrm{g} / \mathrm{mL}$ and is much higher than for example value obtained for silver nanoparticles synthesized by Actinobacteria CGG 11n and Nocardiopsis valliformis strain OT1 (RaileanPlugaru et al. 2016; Rathod et al. 2016). These results suggest that the synthesized LCLB56-AgNCs show the interest for future as a potentially safe agent for treatment of oral and external bacterial infections.

Acknowledgments This work was supported by Maestro-6, No. 2014/14/A/ST4/00641 (2015-2017), and Opus 11 No. 2016/21/B/ST4/ 02130 (2016-2019) from the National Science Centre, Poland. We would like to thank to Prof. H. Dahm and her team from Department of Microbiology, Nicolaus Copernicus University, Torun, Poland for delivering of silver bionanoparticles obtained in framework of Symfonia_I project and used for cytotoxicity comparison in this study.

\section{Compliance with ethical standards}

Conflict of interest The authors declare that they have no conflict of interest.

Ethical approval This article does not contain any studies with human participants or animals performed by any of the authors.
Open Access This article is distributed under the terms of the Creative Commons Attribution 4.0 International License (http:// creativecommons.org/licenses/by/4.0/), which permits unrestricted use, distribution, and reproduction in any medium, provided you give appropriate credit to the original author(s) and the source, provide a link to the Creative Commons license, and indicate if changes were made.

\section{References}

Altschul SF, Madden TL, Schäffer AA, Zhang J, Zhang Z, Miller W, Lipman DJ (1997) Gapped BLAST and PSI-BLAST: a new generation of protein database search programs. Nucleic Acids Res 25: 3389-3402

Ammor S, Yaakoubi K, Chevallier I, Dufou E (2004) Identification by fluorescence spectroscopy of lactic acid bacteria isolated from a small-scale facility producing traditional dry sausages. J Microbiol Methods 59:271-281

Bharat A, Makwana DJ, Vyas KD, Bhatt SD, Vinod KJ (2016) Novel fluorescent silver nanoparticles: sensitive and selective turn off sensor for cadmium ions. Appl Nanosci 6:555-566

Buszewski B, Railean-Plugaru V, Pomastowski P, Rafińska K, SzultkaMlynska M, Golinska P, Wypij M, Laskowski D, Dahm H (2016) Antimicrobial activity of biosilver nanoparticles produced by novel Streptacidiphilus durhamensis strain. J Microbiol Immunol Infect doi:10.1016/j.jmii.2016.03.002

Carminati D, Tidona F, Fornasari ME, Rossetti L, Meucci A, Giraffa G (2014) Biotyping of cultivable lactic acid bacteria isolated from donkey milk. Lett Appl Microbiol 9:299-305

Chatterjea (2004) Textbook of biochemistry for dental/nursing/pharmacy students. Medical Publisher, Jaypee Brothers, pp 51

Cherusova S, Epple M (2013) Silver as antibacterial agent: ion, nanoparticle, and metal. Angew Chem 52:1636-1653

Ciobanu CS, Groza A, Iconaru SL, Popa CL, Chapon P, Chifiriuc MC, Hristu R, Stanciu GA, Negrila CC, Ghita RV, Ganciu M, Predoi D (2015) Antimicrobial activity evaluation of silver doped hydroxyapatite/polydimethylsiloxane composite layer. Biomed Res Int. doi:10.1155/2015/926513

Dec M, Urban-Chmiel R, Gnat S, Puchalski A, Wernicki A (2014) Identification of Lactobacillus strains of goose origin using MALDI-TOF mass spectrometry and 16S-23S rDNA intergenic spacer PCR analysis. Res Microbiol 165:190-201

Delgado S, Rachid CT, Fernández E, Rychlik T, Alegría Á, Peixoto RS, Mayo B (2013) Diversity of thermophilic bacteria in raw, pasteurized and selectively-cultured milk, as assessed by culturing, PCRDGGE and pyrosequencing. Food Microbiol 36:103-111

Dubey P, Matai I, Uday Kumar S, Sachdev A, Bhushan B, Gopinath P (2015) Perturbation of cellular mechanistic system by silver nanoparticle toxicity: Cytotoxic, genotoxic and epigenetic potentials. Adv Colloid Interf Sci 221:4-21. doi:10.1016/j.cis.2015.02.007

Haris PI, Severcan F (1999) FTIR spectroscopic characterization of protein structure in aqueous and non-aqueous media. J Mol Catal B Enzym 7:207-221

Hendrik N, Halket JM (2004) MALDI post-source decay and LIFT-TOF/ TOF investigation of $\alpha$-Cyano-4-Hydroxycinnamic acid cluster interferences. J Am Soc Mass Spectrom 15:336-343

Humberto P (2014) Antimicrobial polymers with, metal nanoparticles. Int J Mol Sci 16:2099-2116

Innocent B, Bekard D, Dunstan E (2009) Tyrosine autofluorescence as a measure of bovine insulin fibrillation. Biophys J 97:2521-2531

Jalaluddin M, Ashraf MAA, Haris MK, Mohammad A, Alzohairy IC (2016) Green synthesis of silver nanoparticles and characterization 
of their inhibitory effects on AGEs formation using biophysical techniques. Sci Rep 6:1-10

Jia K, Wang P, Liting Y, Zhou X, Chenb W, Liu X (2015) Facile synthesis of luminescent silver nanoparticles and fluorescence interactions with blue-emitting polyarylene ether nitrile. J Mater Chem C 3:3522-3529

Kumar S, Stecher G, Tamura K (2016) MEGA7: molecular evolutionary genetics analysis version 7.0 for bigger datasets. Mol Biol Evol 33: 1870-1874

Kun J, Pan W, Liting Y, Xuefei Z, Wenjin C, Xiaobo L (2015) Facile synthesis of luminescent silver nanoparticles and fluorescence interactions with blue-emitting polyarylene ether nitrile. J Mater Chem C 3:3522-3529

Martín R, Heilig HG, Zoetendal EG, Jiménez E, Fernández L, Smidt H, Rodríguez JM (2007) Cultivation-independent assessment of the bacterial diversity of breast milk among healthy women. Res Microbiol 58:31-37

Matei A, Cornea CP, Matei S, Matei GM, Cogalniceanu G, Rodino S (2015) Biosynthesis of silver nanoparticles using culture filtrates of lactic acid bacteria and analysis of antifungal activity. Dig J Nanomater Biostruct 10:1201-1207

Nei M, Kumar S (2000) Molecular Evolution and phylogenetics. Oxford University Press, New York ISBN: 9780195135855

Nejati F, Babaei M, Taghi-Zadeh A (2016) Characterisation of Lactobacillus helveticus strains isolated from home-made dairy products in Iran. Int J Dairy Technol 69:89-95

Neubeck M, Baur C, Krewinkel M, Stoeckel M, Kranz B, Stressler T, Fischer L, Hinrichs J, Scherer S, Wenning M (2015) Biodiversity of refrigerated raw milk microbiota and their enzymatic spoilage potential. Int J Food Microbiol 211:57-65

Nicolardi S, Palmblad M, Dalebout H, Bladergroen M, Tollenaar RAEM, Deelder AM, van der Burgt Y (2010) Quality control based on isotopic distributions for high-throughput MALDI-TOF and MALDI-FTICR serum peptide profiling. J Am Soc Mass Spectrom 21:1515-1525

Pomastowski P, Szultka M, Kupczyk W, Jackowski M, Buszewski B (2015) Evaluation of intact cell matrix-assisted laser desorption/ ionization time-of-flight mass spectrometry for capillary electrophoresis detection of controlled bacterial clumping. J Anal Bioanal Technol. doi: 10.4172/2155-9872

Pomastowski P, Sprynskyy M, Žuvela P, Rafińska K, Milanowski M, Liu JJ, Yi M, Buszewski B (2016) Silver-lactoferrin nanocomplexes as a potent antimicrobial agent. J Am Chem Soc 138:7899-7909

Quinto EJ, Jimenez P, Caro I, Tejero J, Mateo J, Girbes T (2014) Probiotic lactic acid bacteria. Food Nutr Sci 5:1765-1775
Railean-Plugaru V, Pomastowski P, Wypij M, Szultka-Mlynska M, Rafinska K, Golinska P, Dahm H, Buszewski B (2016) Study of silver nanoparticles synthesized by acidophilic strain of Actinobacteria isolated from the of Picea sitchensis forest soil. J Appl Microbiol 120:1250-1263

Rathod D, Golinska P, Wypij M, Dahm H, Rai M (2016) A new report of Nocardiopsis valliformis strain OT1 from alkaline Lonar crater of India and its use in synthesis of silver nanoparticles with special reference to evaluation of antibacterial activity and cytotoxicity. Med Microbiol Immunol 205:435-447

Salunke GR, Ghosh S, Santosh Kumar RJ, Khade S, Vashisth P, Kale T, Chopade S, Pruthi V, Kundu G, Bellare JR, Chopade BA (2014) Rapid efficient synthesis and characterization of silver, gold, and bimetallic nanoparticles from the medicinal plant Plumbago zeylanica and their application in biofilm control. Int $\mathrm{J}$ Nanomedicine 9:2635-2653

Shrivastava S, Bera T, Roy A, Singh G, Ramachandrarao P, Dash D (2007) Characterization of enhanced antibacterial effects of novel silver nanoparticles. Nanotechnology 18:225103-225111

Singh R, Wagh P, Wadhwani S, Gaidhani S, Kumbhar A, Bellare J, Chopade BA (2013) Synthesis, optimization, and characterization of silver nanoparticles from Acinetobacter calcoaceticus and their enhanced antibacterial activity when combined with antibiotics. Int J Nanomedicine 8:4277-4290

Singh R, Nawale LU, Arkile M, Shedbalkar UU, Wadhwani SA, Sarkar D, Chopade BA (2015a) Chemical and biological metal nanoparticles as antimycobacterial agents: a comparative study. Int J Antimicrob Agents 46:183-186

Singh R, Shedbalkar UU, Wadhwani SA, Chopade BA (2015b) Bacteriagenic silver nanoparticles: synthesis, mechanism, and applications. Appl Microbiol Biotechnol 99:4579-4931

Sintubin L, De Windt W, Dick J, Mast J, Van der Ha D, Verstraete W, Boon N (2009) Lactic acid bacteria as reducing and capping agent for the fast and efficient production of silver nanoparticles. Appl Microbiol Biotechnol 84:741-749

Sreeprasad TS, Maliyekkal MS, Deepti K, Chaudhari K, Xavier PL, Pradeep T (2011) Transparent, luminescent, antibacterial and patternable film forming composites of graphene oxide/reduced graphene oxide. ACS Appl Mater Interfaces 3:2643-2654

Vodnar D, Paucean A, Dulf F, Socaciu C (2010) HPLC characterization of lactic acid formation and FTIR fingerprint of probiotic bacteria during fermentation processes. Not Bot Hort Agrobot Cluj 38:109113 